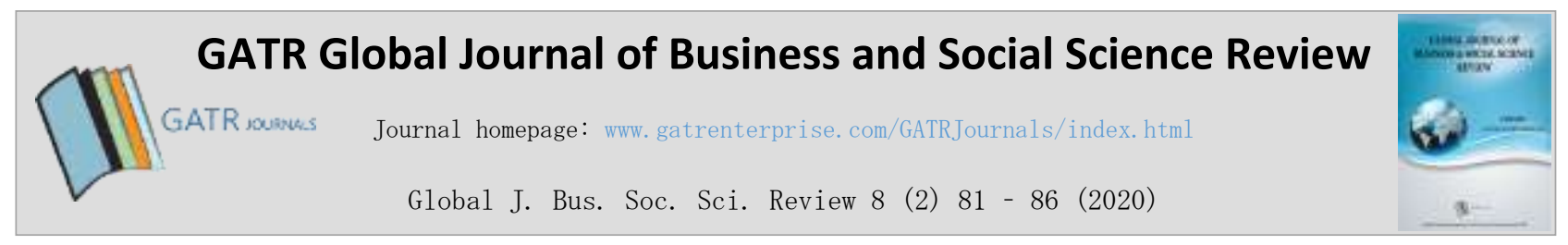

\title{
Entrepreneurial Business Practices among FELCRA’s Women Entrepreneurs $*^{*}$
}

\author{
Ahmad Zamri Mansor ${ }^{1}$, Norasmah Othman², Mohd Maliki Kamarul Zaman ${ }^{3}$ \\ ${ }^{1}$ Centre of Education Leadership and Policy, Faculty of Education, UKM Bangi, Malaysia \\ ${ }^{2}$ Centre of Education Leadership and Policy, Faculty of Education, UKM Bangi, Malaysia \\ ${ }^{3}$ Faculty of Education, UKM Bangi, Malaysia
}

\begin{abstract}
Objective - Women play a significant role in Malaysian economic development. FELCRA is a corporate organization wholly owned by the Malaysian government agency entrusted with the initiative to increase the participation of women in the socio-economic sector. This study aims to explore this issue to address the following research questions: (1) How do they recruit new staff? (2) What are their criteria for hiring new staff? and (3) how do women entrepreneurs train their staff?

Methodology/Technique - This study employs a qualitative approach using in-depth interview. The participants of this study include 6 women entrepreneurs, their ages range from 57 to 62 and all of them are employed in the food industry.

Findings \& Novelty - There are six emerging themes: (1) Reaching out to personal network; (2) Passive candidate sourcing; (3) Disciplined; (4) Personal integrity; (5) Hands-on approach; and (6) Business-specific practical solutions. The findings of this study are beneficial to entrepreneurs and other stakeholders in relation to adapting to good business practices.
\end{abstract}

Type of Paper: Empirical

JEL Classification: M13, L26

Keywords: Malaysia; entrepreneurship; Malaysian Women; Women Entrepreneurs.

Reference to this paper should be made as follows: Zaman, M.M.K; Othman, N; Mansor, A.Z. (2020). Entrepreneurial Business Practices among FELCRA's Women Entrepreneurs, Global J. Bus. Soc. Sci. Review, 8(2): $81-86$. https://doi.org/10.35609/gjbssr.2020.8.2(2)

\section{Introduction}

This paper aims to examine business practices of women entrepreneurs in Malaysia. Women play a significant role in Malaysia's economic development. One of the areas that requires women participation is entrepreneurship. The Malaysian government views the increased participation of women in entrepreneurship as an indication that the initiative to improve socio-economic development is beginning to produce results.

\footnotetext{
${ }^{*}$ Paper Info: Revised: March 11, 2020

Accepted: June 2, 2020

* Corresponding author: Ahmad Zamri Mansor

E-mail: azamri@ukm.edu.my

Affiliation: Centre of Education Leadership and Policy, Faculty of Education, UKM Bangi, Malaysia
} 
One of the government agencies instrumental in this initiative is the Federal Land Consolidation and Rehabilitation Authority (FELCRA). FELCRA's objective is to reduce the poverty rate and the income gap between urban and rural areas. The effort to increase the number of Malaysian women entrepreneurs has been led by FELCRA's Entrepreneurship Management Division (EMD). In 2017, EMD FELCRA Berhad reported that there were 980 women entrepreneurs of a total of 1,600 entrepreneurs registered with them (EMD, 2017). This paper seeks to broaden our understanding of the business practices of women entrepreneurs in Malaysia.

\section{Literature Review}

In terms of recruitment methods used by Malaysian employers, a review of existing literature reveals 3 emerging trends: (1) the increasing popularity of online recruitment tools (Mat Din et. al., 2016; Juariyah 2015; and Tong, 2008); (2) the preference of personal networks ("Job seekers in Malaysia prefer personal networking", 2019); and (3) considerations of cost effectiveness (Raja, 2015). The use of online tools such as social media and online boards are becoming more widespread. Din et. al. (2016) propose the use of social media as a cost-effective recruitment strategy. Hays poll meanwhile, reveals that about $50 \%$ of respondents use online job boards to find a job. The situation is similar in Indonesia. According to Juariyah (2015), who studies recruitment processes in restaurants and cafes in Malang District, Indonesia, employers use BBM, Instagram, and Twitter as recruitment channels. Cost considerations are always the most relevant factor to this (Raja, 2015), particularly for small scale industries.

In terms of recruitment criteria, Manap et. al. (2017), who studied recruitment criteria in Malaysian's construction industry, found that Malaysian employers prefer young, experienced, knowledgeable, and skilled workers. What about academic excellence? According to Hashim (2012), academic excellence should not be considered as a recruitment criterion as her study shows academic performance is not a determinant for performance.

In terms of the training methods used by Malaysian employers, a review of the literature reveals 2 emerging trends: (1) in-house training; and (2) on-the-job training (Abdullah, 2009). Abdullah (2009) found that SSIs (small scale industries) had a high preference for in-house training. The methods consist of demonstrations of the job itself and a hands-on practical approach (Abdullah, 2009).

It is also pertinent to highlight the challenges faced by women entrepreneurs in Malaysia. Hossain et. al. (2018), in reviewing studies related to these challenges, proposed 4 major categories: resource, personal, economic and political, and cultural challenges. They highlight the fact the resource challenges are mainly encountered when the women begin to venture into a new business. There are three aspects of resource challenges: information resources, financial resources and human resources (Hossain et. al., 2018).

The current study aims to answer the following questions: (1) How do they recruit new staff; (2) What are their criteria for hiring new staff? and (3) how do women entrepreneurs train their staff?

\section{Research Methodology}

This is a qualitative research that explores management practices among Malaysian women entrepreneurs. The design is based on Creswell (2009), with the qualitative approach being "a means for exploring and understanding the meaning individuals or groups describe to a social or human problem".

The study was conducted in FELCRA Berhad, Seberang Perak, about 190 km north of Kuala Lumpur, Malaysia. The site was chosen due to the active participation of women entrepreneurs in the area. Informants were selected using snowball sampling. Six women entrepreneurs were recruited as informants. An important consideration in selecting these informants, besides fulfilling the purpose of the study, was their willingness to share their experiences (Chua, 2006). Others were recruited based on recommendations from the first few informants who were interviewed (Mutiah et. al., 2008; Othman, 2007), as well as on the basis of the researchers' evaluations of the value of the contribution they could offer in answering the research questions. 


\subsection{Participants' Profile}

The summary of the participants' background is represented in Table 1. Pseudonyms are used to protect their identity.

Table 1. Summary of Participants’ Background

\begin{tabular}{cccccc}
\hline Participants & Age & $\begin{array}{c}\text { Education } \\
\text { Level }\end{array}$ & $\begin{array}{c}\text { Marital } \\
\text { Status }\end{array}$ & $\begin{array}{c}\text { Type of } \\
\text { Industry }\end{array}$ & $\begin{array}{c}\text { Age When Started } \\
\text { Business }\end{array}$ \\
\hline Satinah & 57 & SPM & Married & Food & 25 \\
Dahlia & 62 & UPSR & Married & Food & 30 \\
Tina & 58 & PMR & Married & Food & 40 \\
Embun & 62 & UPSR & Married & Food & 35 \\
Limah & 57 & PMR & Married & Food & 33 \\
Enon & 59 & UPSR & Married & Food & 30 \\
\hline
\end{tabular}

The ages of the research participants range from 57 to 62 . Their education level is varied, with the highest being Satinah who is a SPM holder. Tina and Limah each hold a PMR while Dahlia and Embun hold a UPSR. SPM stands for Malaysia Education Certificate and is equivalent to Year 11 in the United States, General Certificate of Education Ordinary Level in the United Kingdom and Year 10 in Australia (StudyMalaysia.com, 2019). All of them are married and are employed in the food business. Their ages when they first started their businesses ranged from 25 to 40 .

\section{Results}

There are six emerging themes, as summarized in Table 2.

Table 2. Emerging Themes

\begin{tabular}{cc}
\hline Research Questions & Themes \\
\hline How do they recruit new staff? & $\begin{array}{c}\text { Reaching out to personal network } \\
\text { Passive candidate sourcing }\end{array}$ \\
What are the criteria for & Disciplined \\
recruiting new staff $?$ & Personal integrity \\
How do they train their staff? & Hands-on approach \\
& Business-specific practical solutions \\
\hline
\end{tabular}

\subsection{How do they recruit new staff?}

In terms of staff recruitment, the informants utilized their personal network and selected the applicants from their recruitment database. Dahlia, Enon and Tina narrated their experience in reaching out to their personal networks:

'I do not "formally" advertise job vacancy... it would be enough if I just spread the words among friends and neighbors....' (Dahlia)

'I would spread the word (about the job vacancy) to my neighbors and relatives...' (Enon) 
'If I need new staff, I will contact my friends...' (Tina)

They concentrated on active candidate sourcing, where the applicants would visit the office to apply for job vacancies. The selected applicants would then be notified whenever vacancies emerged.

'I do not advertise job vacancy; they themselves come to my office to get the job.... I keep their telephone numbers and I contact them if I need them to work, especially in my catering business with demand that fluctuates frequently...' (Satinah)

'There are many who came to apply for the job...but I only hire based on need...' (Embun)

'It is easy to get new staff...because many came to apply for the job...' (Limah

\subsection{What are the criterion for recruiting new staff?}

In the interviews conducted, the informants reported that discipline and personal integrity were prioritized when selecting new staff. For example:

... important qualities that I look for if I am to hire new staff. First, ... disciplined and friendly... if they have these qualities, I will put them as my priority...' (Satinah)

'If (the staff) is not disciplined, my business will be affected...' (Dahlia)

'Every staff must have discipline in them. That's the first thing I evaluate in staff recruitment...' (Enon)

Personal integrity is another quality the participants were expecting from new staff. This is clearly evident from the Embun statements:

'I prefer those who are honest and trustworthy...these are very important...' (Limah)

'...the staff's attitude because if one has the positive attitude, Allah will make things easier for him...' (Limah)

'...the staff must be sincere and honest....' (Embun)

\subsection{How do they train their staff?}

The participants train their staff using a hands-on approach focusing on business-specific, practical solutions. The hands-on approach was evident as demonstrated in the following quotes:

"I did not send my employees for any training, but I did train them on ethics, how to dress, and how to serve VVIP in any events that involved VVIP" (Satinah)

"I'd demonstrate to them how to communicate correctly." (Limah)

"If their skill is not good, I'd show them the right way." (Dahlia)

The hands-on training is featured by business-specific practical solutions, i.e. it deals with day to day business operations as mentioned by Embun, Limah and Enon: 
'There are trainings that I gave ... for example I taught them how to make chips until the packaging process ...' (Embun)

'I did train my staff ... so that they can start their own business ...' (Limah)

'I taught them how to make many varieties of chips...' (Enon)

\section{Discussion}

In this study, the women entrepreneurs utilise their personal networks to recruit new staff. This is in line with the statement that "Job seekers in Malaysia prefer personal networking" (2019 observation). The women also used 'passive candidate sourcing' which means that they did not have an active recruitment drive in order to look for suitable candidate for their SME. The 'passive candidate sourcing' approach can be attributed to the cost factor as found by Raja (2015). The women entrepreneurs interviewed also did not mention using online recruitment tools although studies (for example, Mat Din et. al., 2016; Juariyah 2015; Tong, 2008) indicate that the online recruitment tools are gaining popularity. This reflects the urgency to use cost effective strategies in recruitment although online recruitment tools are yet to gain acceptance. This is in line with Hossain et. al.'s (2018) study which states that financial resources is one of the challenges faced by Malaysian women entrepreneurs.

In terms of recruitment criteria, the women interviewed look for those who have discipline and personal integrity. The focus on personal characteristics rather than job-related qualities such as knowledge and experience reveals the lack of strategic human resources planning in managing their enterprises as highlighted by Idrus et. al. (2014) and Hossain et. al. (2018). As a comparison, Manap et. al. (2017) found that Malaysian employers prefer young, skilled, knowledgeable, and experienced employees.

The common training method of using a hands-on approach as reported by the women entrepreneurs interviewed are in line with Abdullah's (2009) study. According to Abdullah (2009), the training methods used by small scale industries (SSI) are demonstrations of the job itself, and a hands-on practical approach.

\section{Conclusion}

The findings show that there are a number of issues affecting the sustainability of the women entrepreneurs in managing their business, namely: the minimal exposure to new technologies, the non-proactive approach in recruitment practices, the cost-conscious approach of staff training and the absence of a proper human resource planning. In order to be more competitive, the change required is not just the replacing the old business practices with the new ones, but also the shifting of mind-set.

In conclusion, the findings of this study are beneficial to entrepreneurs and other stakeholders in relation to adapting to good business practices. The findings make plain the challenges faced by women entrepreneurs, such as the development of good business practices which certainly need to be improved.

For policy makers and training providers in FELCRA and other agencies, they can be informed and guided by these findings to be better able to design training modules that reflect women entrepreneurs' needs. The enculturation of good business practices is certainly an element that should be instilled in the training modules.

\section{References}

Abdullah, H. (2011). Implementing Training in Manufacturing Firms: Training Methods, Venue and Provider. recovered from: http://www. jgbm. org/page/7\% 20Haslinda\% 20Abdullah. pdf. 
Chua, Y. P. (2006). Investigation methods and statistics. Method of investigation. Book 2.

Entrepreneurship Management Division (EMD). (2017). Meeting report of FELCRA Berhad Bill. 1/2017. Perak, Malaysia.

Juariyah, L. (2015). Recruitment and Selection Process in Restaurant and Cafe Industry in Malang City. http://hdl.handle.net/11617/6340

Hashim, J. (2012). Academic excellence as selection criteria among Malaysian employers. Higher Education, Skills and Work-Based Learning. https://doi.org/10.1108/20423891211197758

Hossain, J., Jahangir, N., \& Nur-Al-Ahad, M. (2018). A study on female entrepreneurs in Malaysia. DOI: 10.21272/bel.2(3).67-73.2018

Idrus, S., Pauzi, N. M., \& Munir, Z. A. (2014). The effectiveness of training model for women entrepreneurship program. Procedia-Social and Behavioral Sciences, 129, 82-89. https://doi.org/10.1016/j.sbspro.2014.03.651

Manap, N., Noh, N. M., \& Syahrom, N. (2017, December). Recruitment criteria and attraction strategies for local trained labour in Malaysia's construction industry. In IOP Conference Series: Earth and Environmental Science (Vol. 109, No. 1, p. 012011). IOP Publishing. https://iopscience.iop.org/article/10.1088/1755-1315/109/1/012011/meta

Din, S. Z. M., Anuar, R. H. M., Omar, N., Omar, H., \& Dahlan, J. M. (2015). Discovering the use of online recruitment via social media of student internship. Procedia Economics and Finance, 31, 856-860. https://doi.org/10.1016/S22125671(15)01181-8

Muthiah, P., Abdul Rahim, R., Naidu, R. S., Badzis, M., Mat Nayan, N. F., \& Abd Aziz, N. H. (2008). Qualitative research data collection \& data analysis techniques. http://repo.uum.edu.my/1360/

Othman, L. (2007). Qualitative Research: Introduction to Theory and Method (Qualitative Research: Introduction to Theory and Method). Tanjong Malim: Sultan Idris University College.

Nanthini Devi, R. (2015). A study on recruitment methods among manufacturing and service sectors in Malaysia (Doctoral dissertation, Universiti Utara Malaysia). http://etd.uum.edu.my/4595/

StudyMalaysia.com. (2015). Academic qualification equivalence. StudyMalaysia.com. https://www.studymalaysia.com/international/the-national-education-system/academic-qualification-equivalence

Tong, D. Y. K. (2009). A study of e- recruitment technology adoption in Malaysia. Industrial Management \& Data Systems. https://doi.org/10.1108/02635570910930145 